Original Research

\title{
Developing A Model of HOTS Questions for Narrative Reading Text for IX Grade Students of SMPN 2 Jorong
}

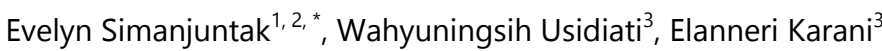 \\ ${ }^{1}$ Teacher at SMPN 2 Jorong, Tanah Laut Regency, South Kalimantan \\ ${ }^{2}$ Alumny of Master of English Education Study Program, University of Palangka Raya \\ ${ }^{3}$ Lecturer at Master of English Education Study Program, University of Palangka Raya \\ *Correspondence: Evelyn Simanjuntak (Email: evelynnnsimanjuntak@gmail.com)
}

\begin{abstract}
Teachers are required to have good reading material with various questions exercises to meet students' interest to improve their reading ability. This developmental research was undertaken to develop a model of instructional material of HOTS questions for narrative reading texts for IX grade students of SMPN 2 Jorong. The development of the model in $R$ \& $D$ research involved the following framework: needs assessment, reference study, material development, expert validation, tryout, revision, and final product. The subject of the research was the students of grade IX of SMPN 2 Jorong. The instruments used were observation sheet, questionnaire sheet, students' test result, and validity and advisability test sheet to take the data. The final product was a Model of HOTS Questions For Narrative Reading Text in the form of instructional material consisting of Cover; Introduction, and Content. The content of the product consisted of 2 Units that contain narrative reading texts with the titles Hansel and Grethel, Malin Kundang, and Rapunzel. Each story was inserted with HOTS questions to ask the students to generalise, to analyse, to compare, to distinguish, and to correlate. Based on the result, the model of HOTS questions was efficient and advisable to be implemented.
\end{abstract}

Keywords

HOTS questions, reading, narrative text, Junior High School (SMP)

\section{INTRODUCTION}

In recent years, many stresses have been given to the teaching of thinking skills in reading classroom. The Indonesian Constitution no 20 year 2003 verse 3 about education purposes on creating faithful, healthy, knowledgeable, smart, creative, and self-supporting students person. Based on the purposes, Higher Order Thinking skills (HOTS) questions exercises are introduced in teaching activities to enable learners to apply their skills in their real life, to analyse them, to evaluate them, and even to think creatively.

For supporting the Indonesian Constitution no 20 year 2003 verse 3, HOTS questions tests are applied in recent National Examinations. They are tested in the form of questions that make the learners think critically, analytically and smart. However, the result of the National Examination, South Kalimantan shows decreasing scores compared with those of 2017. In 2017 the scores were 52.90 and they declined to 51.67 in 2018 with 1.23 percentage difference.
The decline scores may be caused by the teaching activities that do not support the daily activities of giving HOTS questions exercices to the learners. This phenomena also happens in the ninth grade classroom teaching activities in SMPN 2 Jorong. According to the observations, the teachers seldom give HOTS questions exercises to the learners in reading class activities. Furthurmore, this condition is worsened by the supporting student text books that do not add HOTS questions exercises in reading text.

Problem is multiplying in the ninth level of SMPN 2 Jorong. The students analitically thinking is considerebly low. It can be seen by the students' tryout results of final examination held by the school. Only $35 \%$ of the learners get the minimum scores which is targetted by the school.

For solving the serious problem, the researcher tries to make an intsructional material contains questions exercise that may be able to raise students' high order thinking skils. Students' high order thinking skill (HOTS) is a kind of exercises that train learner to think critically and, to solve problems (Brookhart, 2010). 
In reading classroom, teachers need qualified reading materials with some questions excercices to fill students' need to train their higher order thinking. This opinion is like what Miskiah (2015) stated. She said that the learning material plays a very essential role in a learning process, it is the representation of teacher's explanation in the classroom. On the other hand, learning material is one of the learning aid to reach the core competency. Surely it also helps teachers in several learning process, helps learners to perform a determined competency completely and integratedly. Furthermore, learning material may be infered as series of facts, concept, and foundation to make the learning process easier to understand (Abidin, 2012).

This study designs an instructional material about narrative texts with higher order thinking questions exercises that may stimulate student's higher order thinking skills. For Junior High School learners, narrative reading texts are interesting to discuss and they inspire their imagination, critical thinking, and teach good moral values and good models that they may learn from. Relating to that considerations, HOTS questions exercises are suitable to be discussed in learning narrative text, eventhough they also can be applied in many learning materials.

High Order Thinking Skill (HOTS) is in terms of transfer, critical thinking and, problem solving (Brookhart, 2010). HOTS is the ability to think critically, logically, reflectively, metacocnitively, and creatively. Based on this research, HOTS questions mean the questions that can be answered by high thinking order skils which cover 5 (five) key words, they are the questions to generalise, analyse, compare, distinguish, and correlate. The Development of Higher Order Thinking Skill (HOTS) questions exercises is purposefully designed to provide information for teachers to modify the learning material, to help students raising their creativity and to let them think in their own style to solve problems.

The Development of Higher Order Thinking Skill (HOTS) questions exercises may also be trained in narrative reading class activity. Richards and Reinandya (2002) stated that teaching reading process needs 6 (six) levels of thinking process, that is level of knowledge, comprehension, application, analysis, synthesis, and evaluation. These levels should be combined together in the learning process. If the students only learn several levels, the students mind wouldn't grow creatively and think analitically. If the stimuly in the teaching reading process do not cover one of the levels of thinking process it is predicted that that the students are not able to inspire the others to solve several problems they face.

Compared with several previous studies of HOTS questions, this research applied HOTS questions based on a story that is favourable to the teenagers and suitable to junior High School students age, so by the questions they are trying hard to find the probable answer that may raise their higher thinking level.
Developing HOTS questions exercises for reading narrative text also supports the government policy on Curriculum 2013. It has 4 (four) aspects to explore that is the aspects of knowledge, skill, affective, and attitude. It also supports the Minister Regulation No 21 year of 2016. The regulation regulates the Contain Standards of the Midle and the Elementary Education whereas the students should master the core competition includes spiritual attitude, socially attitude, knowlegde, and skill competency.

By this research, hopefully, the design of HOTS questions of narrative text material may improve the students' HOTS level and creates faithful, creative, knowlegable, and self-supporting students in Indonesia. It is expected also be inspireable writing for the other research about how to create and raise smart Indonesia students.

The research of HOTS questions is initiated by Bloom's Taxonomy, whereas the students' analitical ability should be trained by answering several task that ask them to dig their analitical thinking. HOTS questions are also inserted in National Examination question in recent years, however HOTS questions are rarely applied in classroom activities. This research is supposed to fill the student's need of having such exercises.

Dealing with the limitation of the research problem, we propose two research questios. First, how to develop a model of HOTS questions for narrative reading text for IX grade students of SMPN 2 Jorong? Second, how is the effectiveness of a model of HOTS questions for narrative reading text in IX grade students of SMPN 2 Jorong?

Based on these research questions, this research objectives are: (1) to develop a model of HOTS questions for narrative reading text for IX grade students of SMPN 2 Jorong; (2) to find out the effectiveness of a model of HOTS questions for narrative reading text for IX grade students of SMPN 2 Jorong.

\section{METHODOLOGY}

This research is a developmental research. This research is undertaken to design an instructional material of HOTS questions exercise for reading narrative text for the eighth grade students. The study in designinging a supplementary material is for the eight learners of SMPN 2 Jorong. According to Borg (2012) the model involves the following framework procedure, namely: needs assessment, reference study, material development, expert validation, tryout, and final product.

\subsection{Needs Assessment}

Need assessment is planned at the first stage of development to be made in order to get information in terms of topic and kinds of exercises related to the proportion of the supplementary materials. The subjects of the need analysis are the English teacher and the ninth grade students. The English teacher is the one who has 
information of the situation in learning and teaching process and students are the ones who use the developed workbook. There are some activities should be carried out in this step;

Firstly, an informal observation is conducted in order to see the application of HOTS questions in learning narraitive text in SMPN 2 Jorong. These activities are done by observing the process of teaching English and the material in the classroom and having questions and answer session with the students to get the information related to the application of HOTS questions. This activity is also intended to get information about the learning situation and a relevant workbook for the students.

The next activity in this stage is having an interview session with the English teacher. Interview with the English teacher is intended to gather information about the current textbook and the expected product of the workbook. The interview is hold to get information in terms of the aspects of the course description, course outline, current textbook, and the expected, the same questions for teacher are also asked to the students in form of questionaire to make sure that HOTS questions are needed by the students. However, the researcher guides and give the examples of HOTS questions in each number of questionaire when the students answer the questionaire.

\subsection{Material Development}

At this stage, the content is developed. As the supplementary material contains exercises, the activities in this stage will deal with them. After the general instructional objectives are formulated from reference study stage previously, the specific instructional objectives are formulated. The specific instructional objectives are elaborated into indicators that are used to develop the workbook. Relating to the task, material should lead the students to be able to answer HOTS questions. Therefore, the task will cover the demand of course outline.

\subsection{Expert Validation}

The experts who are involved in this stage are the expert in teaching English to Junior High School material, a national examination questions writer, and the second is the expert in education or lecturer. All of the experts validate the content of the workbook through the expert judgment, some consideration related to strength and weaknesses of the instructional material are identified and the content is improved. The criteria of the expert's validation include the language of the text and the questions inserted below the narrative text

\subsection{Try-out}

At this stage, the supplementary material developed is tested to the students to the students, within the purpose to know whether the supplementary material acceptable and useable. The data from try-out will be analyzed and used to revise the product.

\subsection{Revision}

The validation is done by the teachers and the expert of English educations. Based on the inputs and evaluation of the experts, after that the product is revised to further improve quality and get a decent product to be applied.

\subsection{Final Product}

The product is the supplementary instructional material of HOTS questions on narrative text for the ninth grade students in SMPN 2 Jorong. It is in the form of a workbook which consists of practice and project based on the goal and objective required in the course outline.

To make the research is well arranged the researcher applies 4 Instruments development, they are: Observation sheet, scoring sheet of the test result, the test, the test advisability, and normalized Gain formula To determine the effectiveness of developing a model of HOTS questions for narrative reading text.

\section{RESULTS}

\subsection{Need Assesment}

Based on the need assesment result, the average score of the HOTS exercice application reaches 4.2 scores with $84 \%$ (Table 1). It means that the application of HOTS questions in the English classroom activities is seldom applied in the classroom. In this situation, the research of developing the model of HOTS questions is continued.

Table 1. Classroom observation result of need assesment

\begin{tabular}{llcc}
\hline No. & \multicolumn{4}{c}{ HOTS Exercise } & \multicolumn{3}{c}{ Observation } \\
& \multicolumn{1}{c}{ H } & $\mathbf{2}$ & Mean \\
\hline $1 \quad \begin{array}{l}\text { Teacher does not ask to } \\
\text { generalise based on the } \\
\text { narrative text }\end{array}$ & 3 & 4 & 3.5 \\
$2 \quad \begin{array}{l}\text { Teacher does not ask to } \\
\text { analyse based on the narrative } \\
\text { text }\end{array}$ & 4 & 4 & 4 \\
$3 \quad \begin{array}{l}\text { Teacher does not ask to } \\
\text { compare based on the } \\
\text { narrative text }\end{array}$ & 5 & 5 & 5 \\
$4 \quad \begin{array}{l}\text { Teacher does not ask to } \\
\text { distinguish based on the } \\
\text { narrative text }\end{array}$ & 4 & 5 & 4.5 \\
\hline $\begin{array}{l}\text { Teacher does not ask to } \\
\text { correlate based on the } \\
\text { narrative text }\end{array}$ & 5 & 3 & 4 \\
Total score & & & \\
Mean score & $\mathbf{2 1}$ & $\mathbf{2 1}$ & \\
Percentage & $\mathbf{4 . 2}$ & $\mathbf{4 . 2}$ & $\mathbf{4 . 2}$ \\
\hline
\end{tabular}

The result of the need assesment is then continued with the result of the questionaire given to the teacher and the expert to fill on.

The mean score of the teachers, questionaire is 3,18 and the percentage reaches to $63.6 \%$ based on the table of the questionaire scoring (Table 2). It it means that the result fulfils the condition to continue the research of developing the model of HOTS questions.

The result of the student's questionaire also shows 
that the research needs to continue because the students urgently expect the models of HOTS questions introduced in English text book. It shows that the percentage of the questionaire is $84 \%$. It The result of the mean score of the questionaire is 3.98 (4.00) based on the table, it fulfils the condition to continue the research to develop the model of HOTS questions. It means that the model of HOTS questions needs to be developed for the ninth grade students for narrative reading text.

\subsection{Reference Study}

The result of the reference study consists of material of the narrative reading text, the instructional goal based on syllabus, and the course outline. The material is presented in form of text book.

- Narrative Reading Text

The narrative reading text consist of three fairytales, they are Hansel and Grethel, Malin Kundang, and Rapunzel's story.

\section{- The Instructional Goal}

The result instructional goal is shown in Table 2. The material according to the course outline is the text about the fairy tales that have the function to entertain and have several moral values to ponder, text structures, and language features. Based on the Basic Competence, the phrase able to compare contain the part of the ability to think high whereas the students are asked to think deeply about how to differenciate of something by comparing.

- Course Outline

The material outline is the main material which is determined by the goverment. The following table shows the course outline related to the narrative text for the ninth grade students.

\subsection{Material Development}

Result of material development can be obsereved in Table 4 and HOTS questions are served in Tabel 5.

Table 2. Basic competence

\begin{tabular}{lll}
\hline No. & Basic competence & \multicolumn{1}{c}{ Descriptions } \\
\hline 1 & Basic Competence 3,7 & $\begin{array}{l}\text { The students are supposed to be able to compare the social function, text structure, language } \\
\text { feature of some narrative text both written and orally by giving and asking the information related } \\
\text { to fairy tales, shortly and simple according to the context. }\end{array}$ \\
2 Basic Competence 4,7 & $\begin{array}{l}\text { The students are supposed to be able To get the meaning contextually related to the social } \\
\text { function, text structure, and language feature on the narrative text both written and orally, very } \\
\text { short and simple related to fairy tales. }\end{array}$ \\
\hline
\end{tabular}

Table 3. The course outline

\begin{tabular}{|c|c|}
\hline Learning Material & Activities \\
\hline $\begin{array}{l}\text { Fairy tales that has several moral values to think about, good } \\
\text { examples, and various characters, simple past tense sentences, } \\
\text { adverbial phrases: a long time ago, once upon a time, in the end, } \\
\text { happily ever after, and the topic gives good model and create } \\
\text { good characters. }\end{array}$ & $\begin{array}{l}\text { Theacher tells some fairy tales and the students listen to the } \\
\text { story, asksome information related to the story and discuss the } \\
\text { massages from the story. Doing reflexion based on the process } \\
\text { and the learning results. }\end{array}$ \\
\hline
\end{tabular}

Table 4. Systematic of the material development

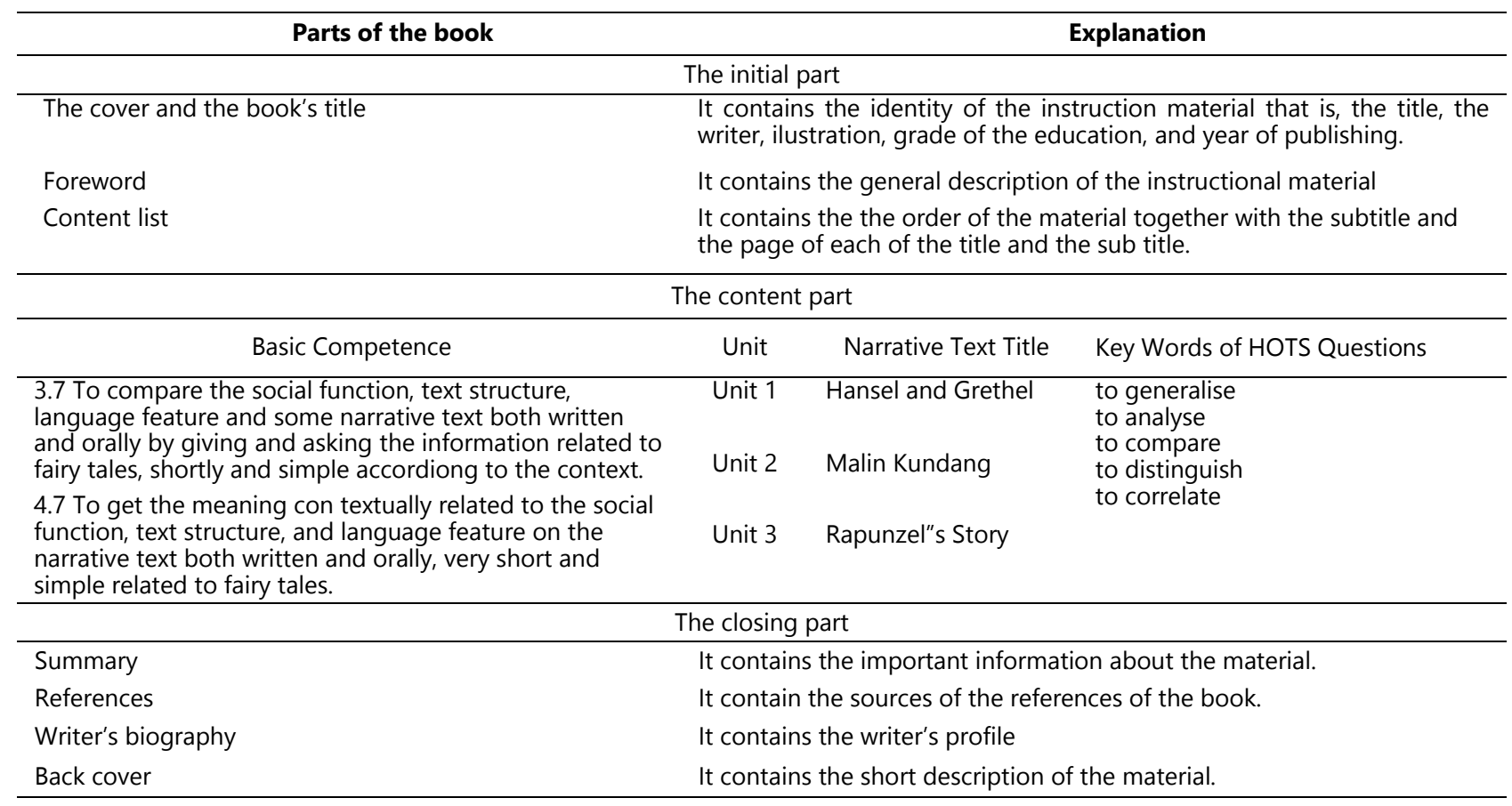


Table 5. List of HOTS Questions

\begin{tabular}{|c|c|}
\hline $\begin{array}{l}\text { Keywords of } \\
\text { HOTS Question }\end{array}$ & The questions Excercise \\
\hline To generalise & $\begin{array}{l}\text { 1. What can you learn from the story? } \\
\text { 2. From the story we can infer that } \\
\text { 3. What is the writer's intention of writing } \\
\text { the story above? }\end{array}$ \\
\hline To analyse & $\begin{array}{l}\text { 1. What probably had made hansel feel } \\
\text { to his Grethel? } \\
\text { 2. Why do you think Malin Kundang } \\
\text { ordered his mother to go away? } \\
\text { 3. What probably had made the witch } \\
\text { hate Rapunzel? }\end{array}$ \\
\hline To compare & $\begin{array}{l}\text { 1. Who do you think had the worst } \\
\text { character based on the story? } \\
\text { 2. What would likely had happened to } \\
\text { Rapunzel if she had lived with her } \\
\text { parents? } \\
\text { 3. What would Malin Kundang likely do if } \\
\text { his mother was rich? }\end{array}$ \\
\hline To distinguish & $\begin{array}{l}\text { 1. Can you give an alternative to make } \\
\text { Malin Kundang save from the curse? } \\
\text { 2. Can you give an alternative to make } \\
\text { Malin Kundang save from the curse? } \\
\text { 3. Who do you think the most patient } \\
\text { character based on the story? }\end{array}$ \\
\hline To correlate & $\begin{array}{l}\text { 1. What would likely happen if the step } \\
\text { mother had loved the children? } \\
\text { 2. What would likely happen if Malin } \\
\text { Kundang had welcome his Mother in } \\
\text { front of his wife? } \\
\text { 3. How did likely Rapunzel think before } \\
\text { she had known her mother? }\end{array}$ \\
\hline
\end{tabular}

\subsection{Expert Validation}

The validaton is made by 2 (two) English teachers. According to their examinations, Table 6 shows the list of the revised question.

Table 6 . The revised questions

\begin{tabular}{|c|c|}
\hline Original question & Revised question \\
\hline $\begin{array}{l}\text { What are the moral value can } \\
\text { we get by reading the story? }\end{array}$ & $\begin{array}{l}\text { What are the moral values } \\
\text { can we get by reading the } \\
\text { story? }\end{array}$ \\
\hline $\begin{array}{l}\text { What made the witch treated } \\
\text { Rapunzel bad? }\end{array}$ & $\begin{array}{l}\text { What probably had made } \\
\text { the witch treated Rapunzel } \\
\text { bad? }\end{array}$ \\
\hline $\begin{array}{l}\text { What was Hansel's character } \\
\text { compared with Grethel? }\end{array}$ & $\begin{array}{l}\text { What was probably Hansel's } \\
\text { character compared with } \\
\text { Grethel? }\end{array}$ \\
\hline $\begin{array}{l}\text { What made Hansel and } \\
\text { Grethel love each other? }\end{array}$ & $\begin{array}{l}\text { What probably had made } \\
\text { Hansel and Grethel love } \\
\text { each other? }\end{array}$ \\
\hline
\end{tabular}

Based on the result, it is categorised into advisable because the result belongs to the highest category. It means that the Product is considered valid because the percentage reaches $81-100 \%$ very advisable to be implemented.

\subsection{Try Out}

The percentage of students score is $68.8 \%$. It means that the HOTS questions excercise need to be revised and continued to the second excercise. Table 7 shows the criteria wheter the test is continued or not.
Tabel 7. Scoring Sheet of the Test Result

\begin{tabular}{cccc}
\hline Scale & Mean Score & Qualification & Follow up \\
\hline 4 & $81-100 \%$ & Very good & Implemented \\
3 & $71-80 \%$ & Good & Implemented \\
2 & $51-70 \%$ & Fairly good & Revised \\
1 & $<50 \%$ & Poor & Revised \\
\hline
\end{tabular}

Based on the scoring sheet, the students' average score is categorized into fairly good and the questions should be revised.

\subsection{Revision}

Revision is essential for developing every model of learning questions. For making the model better, the researcher revises the part of questions to make the students easier to answer the questions. the result of the students mean score is $84.8 \%$ after the questins are revised based on the questions revision. It means that the score is very good and can be answered by almost students with good mark.

\subsection{Final Product}

The product is the supplementary instructional material of HOTS questions on narrative text for the ninth grade students in SMP N 2 Jorong. It is in the form of a workbook which consists of practice and project based on the goal and objective required in the course outline.

To make the research is well arranged the researcher applies 4 Instruments development, they are: Observation sheet, scoring sheet of the test result, the test, the test advisability, and normalized Gain formula To determine the effectiveness of developing a model of HOTS questions for narrative reading text.

\section{DISCUSSION}

The mean score of the teachers questionaire is 3,18 and the percentage reaches to $63.6 \%$ based on the table of the questionaire scoring, it fulfils the condition to continue the research of developing the model of HOTS questions.

The result of the student's questionaire also shows that the research needs to continue because the students urgently expect the models of HOTS questions introduced in English text book. As can be seen from the students' score, it is decided that the HOTS questions can be effectively applied for narrative reading text for IX grade students. And the model of HOTS questions plays significant role in teaching narrative reading text for IX grade students of SMPN 2 Jorong. Furthermore, the model of HOTS questions influences the narrative reading text ability for IX grade students of SMPN 2 Jorong. However, the questions should be easy to 
undertsand and should be suitable to the students' vocabulary and the language of the narrative text should be short with about 400-600 words to help the students easily understand the content.

\section{CONCLUSION}

The designing of HOTS question is done by the following precedures, they are need assesment, material development, expert validation, try-out, revision, and final pruduct. The content of the product consists of three fairy tales, they are Hansel and Grethel, Malin Kundang, and Rapunsel. Each story completed with HOTS questions excercise with the questions to ask the students to generalise, to analyse, to compare, to distinguish, and to correlate. The design of HOTS questions plays significant role in teaching narrative reading text for the eighth grade learners of SMPN 2 Jorong.

The design of HOTS questions will influence the understanding of narrative reading text ability for the eighth grade students of SMPN 2 Jorong. It is suggested to insert several HOTS questions in some students' reading text, to introduce English teachers to some example of HOTS questions for some reading text, and to do some research about HOTS question related to students learning material.

\section{REFERENCES}

Abidin, Y., 2012. Pembelajaran bahasa berbasis pendidikan karakter. Refika Aditama.

Brookhart, S.M., 2010. How to assess higher-order thinking skills in your classroom. ASCD.

Miskiah, M., 2015. Peran Bahan Ajar dalam Pembelajaran. (Online). Retrieved from: (http://bdkpalembang. kemenag.go.id, on 3 November 2017.

Richards, J.C. and Renandya, W.A. (eds.), 2002. Methodology in language teaching: An anthology of current practice. Cambridge university press. 